Tabun XIV Volume 14 Nomor 1 Edisi 31 Juli 2020

ISSN 0216-079X E-ISSN 2685-3043

Balai Bahasa Kalimantan Barat

\title{
PERWUJUDAN HISTORIS SEBAGAI REPERTOIRE DALAM \\ TENGGELAMNYA KAPAL VAN DER WIJCK KAJIAN ESTETIKA WOLFGANG ISER
}

\section{HISTORICAL MATERIALIZATION AS REPERTOIRE IN HAMKA'S TENGGELAMNYA KAPAL VAN DER WIJCK NOVEL AESTHETIC STUDIES BY WOLFGANG ISER}

\author{
Daratullaila Nasri \\ Balai Bahasa Provinsi Sumatra Barat \\ daratullaila.nasri@kemdikbud.go.id
}

\begin{abstract}
ABSTRAK
Tulisan ini membicarakan perwujudan historis sebagai repertoire dalam roman Tenggelamnya Kapal van der Wijck Karya Hamka. Repertoire adalah sebuah konsep yang melekat pada teori estetika resepsi yang digagas oleh Wolfgang Iser. Repertoire merupakan gudang pengetahuan yang dimiliki pengarang yang meliputi unsur kebudayaan diantaranya (sejarah, sosial, dan budaya). Metode penelitian ini berpijak pada estetika resepsi sastra, yaitu strategi pembacaan dan interaksi antar teks dan pembaca. Penelitian ini menghasilkan perwujudan historis dalam bentuk background (latar belakang) dan foreground (latar depan). "Paham merah" atau PKI yang dimunculkan dalam teks dikatakan sebagai background dalam roman Tenggelamnya Kapal van der Wijck. Background ini yang menggiring interpretasi pembaca untuk memahami foreground, yakni tokoh Zainuddin merupakan gambaran tokoh sejarah PKI di Padang Panjang, yaitu Natar Zainuddin. Hal itu diperkuat dengan hadir tokoh Muluk--sahabat terdekat Zainuddin--yang dikaitkan dengan tokoh Muluk Nasution. Akibat pengaruh paham yang dibawa kedua tokoh tersebut, terjadi pasang surut dalam perjalan hidup Haji Rasul di Sumatera Thawalib. Hal itu dinterpretasikan lewat judul drama "Terusir" dan "Kembali" yang ditulis Zainuddin.

Kata Kunci: estetika resepsi, repertoire, background, foreground
\end{abstract}

\begin{abstract}
This paper reviews historical materialization as repertoire in Hamka's Tenggelamnya Kapal van der Wijck novel. Repertoire is a concept attached to a theory of aesthetic response by Wolfgang Iser. Repetoire is a collection of knowledge owned by authors, consisting cultural elements (history, social, culture). Research method focused on aesthetic response which is about reading strategy and the interaction between text and its reader. It resulted in historical materialization in the form of background and foreground. "Paham Merah"/"Red Idealism" or PKI that appears in the text is stated as background in Tenggelamnya Kapal van der Wijck novel. Background leads reder's interpretation to understand foreground which is Zainuddin was PKI historical figure in Padang Panjang, Natar Zinuddin. It is supported by the presence of Muluk-Zainuddin's best friend-whom related to Muluk Nasution. The effect of
\end{abstract}


Tuab Talino

Tahun XIV Volume 14 Nomor 1 Edisi 31 Juli 2020

ISSN 0216-079X E-ISSN 2685-3043

Balai Bahasa Kalimantan Barat

idealism brought by them was the ups and downs of Haji Rasul's career in Sumatera Thawalib. It is also interpreted in a drama titled "Terusir" and "Kembali" by Zainuddin.

Keywords: aesthetic response, repertoire, background, foreground

\section{PENDAHULUAN}

Tenggelamnya Kapal van der Wijck adalah karya populer. Agaknya tidaklah berlebihan kalau roman Tenggelamnya Kapal van der Wijck dikatakan sebagai karya populer, paling tidak pada zamannya. Mengapa? Hal ini dapat dilihat dari dua sisi. Pertama, dari sisi pengarang. Tenggelamnya Kapal van der Wijck diciptakan oleh Hamka, seorang ulama besar yang tidak hanya dikenal di Indonesia, Asia, bahkan dunia. Sebagai seorang ulama, beliau tidak hanya dikenal sebagai pendakwah saja, tetapi dia juga dikenal dari buku-buku dan artikel-artikel yang ditulisnya. Kedua, dari sisi karya, Tenggelamnya Kapal van der Wijck adalah sebuah roman yang mengisahkan percintaan laki-laki dan perempuan yang sangat menggugah perasaan dan mengguras air mata. Menurut Dahlan (2011:24) gaya penceritaan seperti itu digemari pembaca karena pada zaman itu hampir tidak ada novel percintaan yang ditulis oleh pengarang Indonesia.

Dari kedua sisi tersebut dapat digaris bawahi bahwa seorang ulama menulis roman percintaan. Tidak semua orang dapat menerima pemahaman ini. Akan tetapi, hal itu adalah kenyataan yang ada di depan mata. Tidaklah mengherankan kalau ulama pada zaman itu sangat menentang apa yang telah diperbuat Hamka. Hal itu beliau nyatakan dalam 'Pendahuluan Cetakan Keempat' (1982: 5).

"Sesungguhnya bagi seorang golongan agama, mengarang sebuah buku roman, adalah menyalahi kebiasaan yang umum dan lazim pada waktu itu. Dari kalangan agama pada mulanya, saya mendapat tantangan keras. Tetapi setelah 10 tahun berlalu, dengan sendirinya heninglah serangan dan tantangan itu, dan kian lama kian mengertilah orang apa perlunya kesenian dan keindahan dalam hidup manusia".

Tidak hanya cukup sampai di situ, sekitar tahun 1962-1964 (Dahlan, 2011) setelah Tenggelamnya Kapal van der Wijck mengalami 7 kali cetak ulang, Tenggelamnya Kapal van der Wijck kembali menjadi pembicaraan hangat. Pembicaraan itu diawali dengan keluarnya tulisan Abdullah Sp di Bintang Timur, 7 September 1962 dengan judul "Hamka, Benarkah Dia Manfaluthi Indonesia". Tulisan tersebut intinya menyatakan bahwa roman Tenggelamnya Kapal van der Wijck merupakan hasil plagiat. Abdullah Sp. melihat bahwa Tenggelamnya Kapal van der Wijck jiplakan dari Al Majdulin (Maghdalena) karya Mustafa Luthfi AlManfaluthi. Dalam tulisannya itu Abdullah SP. (1962: 8) sangat yakin bahwa Hamka telah menjiplak baik dari segi tema, isi, maupun nafasnya. Selanjutnya, menurut Abdullah SP. perbedaanya "cuma tempat kejadian dan tokoh-tokoh yang disulap dengan menggunakan warna setempat".

Tanggapan atas kekisruhan itu dapat dilihat dari hasil wawancara Hamka dengan wartawan Berita Minggu tahun 1962 (Hamzah dan Jassin, 1963: 26). Hamka sendiri menanggapi bahwa dirinya tidak akan menanggapi "fakta yang dicampur adukkan dengan opini”. Selanjutnya Beliau menyarankan agar Fakultas 
Sastra Universitas Indonesia atau Panitia Kesusastraan membuat komisi khusus atas kasus ini. Melalui media tersebut Hamka bersedia mempertanggungjawabkan karyanya.

Namun, ketika sang wartawan Berita Minggu menanyakan kepada Hamka tetang Tenggelamnya Kapal van der Wijck apakah jiplakan atau tidak jiplakan dari Majdulin karya Manfaluthi. Dari tulisan Hamzah (1963: 26) dipaparkan, bahwa Hamka dengan sedikit bernafsu memberikan jawaban "Saya akui saya memang sangat terpengaruh oleh Manfaluthi. Dan itu sudah disinyalir dalam Ensiklopedia Indonesia tahun 1952 halaman 70 yang mengakatan bahwa Hamka terpengaruh oleh Manfaluthi dan itu saya benarkan".

Di akhir wawancara tersebut Hamka menyatakan bahwa "sebagai seorang yang beragama saya percaya dengan keadilan Tuhan, maka sekiranya saya salah sudah pasti saya akan jatuh, tetapi payahlah orang itu akan menjatuhkan saya" (Hamzah dan Jassin, 1963: 26). Pada saat itu, Hamka tidak sedikit pun membukakan tabir rahasia Tenggelamnya Kapal van der Wijck. Pada akhirnya kehebohan tetang kasus plagiat itu pun menguap begitu saja.

Seiiring berjalannya waktu, Tenggelamnya Kapal van der Wijck masih tetap menarik dan populer untuk dibicarakan hingga saat ini. Yang paling spektakuler adalah diangkatnya roman Tenggelamnya Kapal van der Wijck ke layar lebar oleh Ram Soraya pada tahun 2013. selain itu, di kalangan akademisi pun roman Tenggelamnya Kapal van der Wijck juga menjadi objek kajian ilmiah. Hal itu tentu tidak terlepas dari isi yang terkandung dalam teks roman tersebut.

Menurut Nasri (2015:6) melalui tokoh cerita dalam Tenggelamnya Kapal van der Wijck Hamka menyuarakan beberapa persoalan, di antaranya adalah Islam dan adat Minangakabau, persentuhan budaya yang berbeda, persoalan modernitas yang dihadapkan dengan tradisi masyarakat, dan persoalan status sosial. Demikian pula halnya dengan pandangan Teeuw (1980: 105-106), bahwa Hamka menghasilkan sebuah buku yang amat berbeda sifatnya, baik isi maupun latar belakang yang bersifat Indonesia seluruhnya, dan sedikit banyaknya bersifat otobiografis. Lain lagi halnya dengan Hamzah (1963) yang melihat dari sisi gaya bahasa yang digunakan Hamka dalam Tenggelamnya Kapal van der Wijck. Menurut Hamzah, kepenulisan Hamka seperti gaya penulisan kaba (cerita tradisional Minangkabau). Selain itu, dalam teks roman tersebut juga banyaknya ditemukan gaya bahasa kias. Junus (1989) justeru memandang bahwa Tenggelamnya Kapal van der Wijck masih terikat dengan suatu peristiwa sejarah.

Mengacu pada paragraf di atas, penulis melihat bahwa Tenggelamnya Kapal van der Wijck merupakan "gudang pengetahuan" (repertoire) Hamka tetang budaya dan sejarah pada zamannya. Hal itu tidak bisa dinafikan lagi karena teks Tenggelamnya Kapal van der Wijck membuktikannya. "Gudang pengetahuan" atau repertoire adalah istilah yang dikemukakan oleh Iser dalam bukunya yang berjudul The Art of Reading: a Theory of Aesthetic Response (1987). Tulisan ini bermaksud membicarakan bagaimana perwujudan historis dalam Tenggelamnya Kapal van der Wijck sebagai repertoire.

Sejauh amatan penulis, penelitian tetang Tenggelamnya Kapal van der Wijck dengan konsep repertoire yang dikemukakan oleh Iser belum pernah dilakukan. Akan tetapi, tulisan-tulisan yang terkait dengan objek roman tersebut 
di antaranya dapat dikemukakan di sini. Artikel ilmiah yang dijadikan referensi bagi penulisan ini data terbaru, yaitu lima tahun terakhir.

Sebuah artikel yang ditulis Kholidah dan Amri (2019) tentang "Etnosentrisme dalam Tenggelamnya Kapal van der Wijck Karya Hamka dalam Perspektif Strukturasi Giddens". Artikel tersebut menganalisis etnosentrisme dalam roman Tenggelamnya Kapal van der Wijck dengan prespektif strukturasi Giddens. Hasil penelitian ini menunjukkan bahwa gejala etnosentrisme melalui tindakan para tokoh dalam roman merupakan manifestasi struktur penulis. Menurut peneliti, roman Tenggelamnya Kapal van der Wijck merupakan sarana komunikasi Hamka selaku agen yang dimotivasi oleh keinginan akan berbaikan dan perubahan terhadap struktur budaya Minangkabau. Selanjutnya, artikel yang ditulis Musyafir, Lembah dan Kangiden (2017) dengan judul artikel "Ekranisasi Novel Tenggelamnya Kapal van der Wijck ke dalam Film (Pendekatan Struktural)". Fokus penelitian itu pada perubahan yang terjadi pada unsur-unsur instrinsik dari novel Tenggelamnya Kapal van der Wijck setelah diadaptasi menjadi film Tenggelamnya Kapal van der Wijck dengan menggunakan teori ekranisasi dan pendekatan struktural. Untuk memaparkan kajian tersebut, peneliti menggunakan metode deskriptif . "Proses adaptasi (Ekranisasi) Novel "Tenggelamnya Kapal van der Wijck" Karya Hamka" artikel yang ditulis Rizki D. (2017). Tulisan Rizki tersebut menggunakan pendekatan sosiologis. Artikel itu melihat bagaimana proses ekranisasi atau adaptasi dapat mendeskripsikan alur cerita, tokoh dan penokohan, serta latar belakang hegemoni budaya Minang dalam kompleksitas peristiwa yang melekat pada tokoh dan karakter dalam film Tenggelamnya Kapal van der Wijck. Berikutnya, artikel yang ditulis Simarmata (2015) dengan judul "Analisis Konflik Tokoh Utama dalam Roman Tenggelamnya Kapal van der Wijck Karya Buya Hamka”. Sesuai dengan judul artikel itu, penelitian terfokus menganalisis konflik internal dan eksternal tokoh utama dalam Tenggelamnya Kapal van der Wijck. Peneliti menggunakan metode deskriptif dalam menganalisis data.

Sebagaimana telah dikemukakan di atas, bahwa tulisan ini berpijak pada estetika resepsi (Iser). Berbicara estetika resepsi, ada dua pemikir hebat yang mencuat dibidang ini, yaitu Jauss dan Wolfgang Iser. Jauss memfokuskan pembahasan resepsinya pada bagaimana pembaca mempelajari karya sastra sejak kemunculannya sampai saat ini. Teori tersebut memprioritaskan sambutan pembaca terhadap karya sastra dari waktu ke waktu (bersifat historis). Ada pun iser memfokuskan pembahsannya pada sambutan pembaca secara umum terhadap teks sastra dan hubungan teks dengan pembaca dalam konteks individual. Konsep utama teori Iser adalah berkaitan dengan repertoire.

Istilah repertoire secara sederhananya disebut oleh Manshur (2007: 35) sebagai "gudang pengetahuan". Repertoire berada dalam ruang lingkup estetika resepsi yang berkaitan dengan cara pembaca memberi makna terhadap karya yang dibacanya. Dengan kata lain, teori ini fokus pada tanggapan pembaca terhadap teks serta hubungan teks dengan pembaca dalam konteks individual (Iser dalam Setyami, 2012: 15). Dalam konteks ini menurut Setyami atas pemahamannya terhadap estetika resepsi Iser, lebih menekankan pada efek/kesan pembaca dalam memahami atau mengkonkretkan teks kesastraan. Selanjutnya dijelaskan bahwa, 
Tuab Talino

Tabun XIV Volume 14 Nomor 1 Edisi 31 Juli 2020

ISSN 0216-079X E-ISSN 2685-3043

Balai Bahasa Kalimantan Barat

konkretisasi teks didukung oleh ketersediaan memori pembaca serta harapan pembaca terhadap teks yang dibacanya.

Meskipun Iser lebih menekankan efek teks bagi pembaca yang terpola melalui titik temu hubungan antara teks dan realita serta hubungan antara teks dengan pembaca, pada dasarnya teori respon estetik yang dikemukakan Iser berimpilikasi pada perspektif sosial. Hal tersebut salah satunya dapat dilihat pada konsep repertoire dan strategi pembacaan.

Menurut Iser (dalam Setyami, 2012: 18) repertoire terdiri atas semua unsur yang dapat dikenali dalam sebuah teks. Unsur-unsur tersebut bisa berupa referensi-referensi terhadap karya terdahulu, atau norma-norma sosial dan historis atau dapat juga keseluruhan unsur kebudayaan yang dimunculkan dalam teks. Unsur-unsur yang dimunculkan dalam teks sastra tersebut disebut background (latar belakang) dan foreground (latar depan). Kedua latar tersebut memberikan efek atau kesan--yang diistilah wirkung oleh Iser--kepada pembaca ketika memahami dan mengkongkritisasi teks sastra. Sementara itu, strategi pembacaan menyangkut cara atau tindakan pembacaan dan interaksi antara teks dan pembaca (Iser dalam Setyami, 2012: 15).

Dengan menggunakan kerangka teori di atas untuk memecahkan permasalahan yang diutarakan dapat dikemukakan hipotesis berikut: roman Tenggelamnya Kapal van der Wijck sebagai sebuah teks memiliki unsur-unsur sosial, historis atau kebudayaan secara menyeluruh. Unsur-unsur tersebut dalam konteks ini, khusus membicarakan perwujudan historis dalam roman Tenggelamnya Kapal van der Wijck.

\section{METODE}

Sumber data penelitian ini adalah roman Tenggelamnya Kapal van der Wijck karya Hamka terbitan 1982. yang menjadi data penelitian adalah unsur yang terkait dengan historis sebagai repertoire dalam Tenggelamnya Kapal van der Wijck.

Metode analisis data penelitian ini berpijak pada estetika resepsi yang digagas Iser. Dalam paradigma teori ini bahwa teks akan bermakna melalui interpretasi pembaca. Oleh karena itu, metode yang digunakan adalah strategi (cara atau tindakan) pembacaan dan interaksi antara teks dan pembaca.

Metode itu dilakukan dengan teknik sebagai berikut, Pertama, membaca teks roman Tenggelamnya Kapal van der Wijck dan menandai dan mencatat bagianbagian yang dianggap sebagai repertoire. Kedua, mengklasifikasikan unsur-unsur kebudayaan yang dianggap sebagai repertoire. Ketiga, menganalisis dan menginterpretasi khusus perwujudan unsur historis sebagai repertoire dalam roman Tenggelamnya Kapal van der Wijck.

\section{PEMBAHASAN}

Tenggelamnya Kapal van der Wijck merupakan "gudang pengetahuan" Hamka tetang kebudayaan dan kehidupan yang dialaminya. Pernyataan itu berlandaskan pada teks yang dimunculkan oleh Hamka dalam roman tersebut. Hal itu dapat dilihat pada background (latar belakang) yang digambarkan Hamka 
dalam roman tersebut. Pada roman itu digambarkan tetang Padang Panjang yang pernah mengalami masa kejayaan dalam bidang perdagangan hingga dunia pendidikan. masa kejayaan itu pun runtuh akibat masuknya paham "merah" (komunis) di negeri itu (Hamka, 1982: 74-75). Kemudian, background itu pun didukung dengan foreground (latar depan), yaitu dengan hadirnya tokoh Zainuddin dan Muluk dalam roman tersebut. Kedua latar di atas dimunculkan Hamka bukan tanpa sebab. Kedua latar itu memberikan efek atau kesan kepada pembaca dalam memahami dan mengkongkritkan teks Tenggelamnya Kapal van der Wijck.

Bagi Hamka sendiri nama Zainuddin memiliki arti penting dalam kehidupannya, terutama sekali dalam kehidupan ayahnya, yaitu Haji Rasul. Tokoh Zainuddin yang dimunculkan Hamka dalam roman Tenggelamnya Kapal van der Wijck agaknya dipengaruhi oleh nama Natar Zainuddin. Natar Zainuddin adalah putra Minangkabau yang hidup di Aceh. Diperantauan, ia berkerja sebagai kernet trem. Pada bulan Mei 1923 pihak Belanda mengirimnya pulang ke Minangkabau akibat adanya kebijakan Belanda memulangkan orang-orang yang dianggap berbahaya ke kampung halamannya masing-masing (Kahin, 2005: 33).

Mengenai kepulangan Natar Zainuddin memunculkan kecurigaan bahwa Belanda sengaja mengirimkan pulang ke Minangkabau (Padang Panjang) karena Natar Zainuddin sudah dikenal Belanda sebagai salah seorang tokoh PKI. Organisasi tersebut (PKI) memang dilarang saat itu karena sering menentang kebijakan Belanda. Bagi Belanda strategi ini merupakan siasat untuk melemahkan dan memecah gerakan-gerakan pembaharuan keagamaan yang dilakukan ulamaulama reformis saat itu di Padang Panjang. Siasat ini cukup berhasil karena Natar Zainuddin mulai menyebarkan paham-paham komunisnya di perguruan Sumatera Thawalib Padang Panjang.

Pada tahun 1923 Natar Zainuddin bertemu dengan Haji Datuk Batuah di Sigli Aceh. Haji Datuk Batuah lahir pada tahun 1895 di Koto Laweh, dekat Padang Panjang. Dia lulusan sekolah dasar Belanda, kemudian menutut ilmu di Mekah selama enam tahun (1909-1915). Setelah kembali ke kampuang halamannya beliau menjadi murid Haji Rasul (ayah Hamka) (Kahin, 2005: 33). Beliau adalah salah seorang murid Haji Rasul yang paling pintar dan dinamis. Oleh karena itu, tidaklah mengherankan beliau bisa menjadi asisten Haji Rasul setelah tahun 1915.

Perkenalan antara Natar Zainuddin dan Haji Datuk Batuah berlanjut dengan bergabungnya kedua orang ini menjadi anggota komunis. Hal itu dipererat setelah mereka bertemu dengan para pemimpin PKI di Jawa, terutama dengan Haji Mohammad Misbach. Tokoh PKI yang satu ini sangat besar pengaruhnya terhadap Haji Datuk Batuah. Ketertarikan Haji Datuk Batuah pada Haji Mohammad Misbach ketika dia menjelaskan sikapnya di kongres Partai Komunis dan Sarikat Islam Merah yang diselenggarakan di awal Maret 1923 (Kahin, 2005: 33). sepak terjang Haji Datuak Batuah dalam menyebarkan pahamnya mulai berkembang di perguruan Thawalib Padang Panjang tempat Haji Rasul Mengajar.

Kahin (2005: 19-20) menjelaskan bahwa dalam rapat mereka di Prambanan pada bulan Desember 1925, Komite Sentral Partai Komunias (KSPK) menyerukan pemberontakan melawan Belanda yang akan dimulai di Sumatera pada bulan Juli 1926. Pemilihan Sumatera Barat sebagai tempat awal 
pemberontakan dilandasi oleh pemikiran seorang Belanda yang bertugas sebagai penasehat Belanda urusan pribumi, yakni Ch.O. Van der Plas bahwa orang Minangkabau adalah orang-orang yang gelisah, dengan tradisi pemberontakan dan perlawanan yang panjang. Kondisi ini sangat memudahkan mereka untuk membangkitkan kembali perlawanan terhadap Belanda yang telah lama terpendam. Untuk menyebarkan pahamnya, Haji Datuk Batuah menerbitkan koran Pemandangan Islam yang dikelolanya bersama Djamaluddin Tamin (juga murid Haji Rasul). Sementara itu, Natar Zainuddin menyuarakan pahamnya melalui korannya Djago-Djago. Kedua koran ini, sama-sama menyuarakan kesamaan Islam dan Komunis dalam perjuangan menentang penjajahan Belanda.

Akhirnya, sepak terjang Natar Zainuddin dan Haji Datuk Batuah tidak berlangsung lama karena pada bulan November 1923 Belanda menangkap kedua tokoh tersebut. Mulanya mereka ditahan di Padang, kemudian dipindahkan ke Boven Digul. Penangkapan keduanya bukanlah dapat melumpuhkan perlawanan, tetapi justeru sebaliknya, jumlah pengikutnya kaum radikalisme ini semakin meningkat dikalangan siswa dan pemuda di Padang Panjang.

Terkait gerakan PKI di Padang Panjang ini, Hamka dalam roman Tenggelamnya Kapal van der Wijck menjelaskan bahwa "Dalam tahun 1923 bergoncang pergaulan murid-murid sekolah-sekolah agama itu lantaran salah seorang guru di antara guru-guru yang begitu banyak, pulang dari pelawatannya ke tanah Jawa telah membawa faham 'merah' (komunis), sehingga sebagian murid-murid kemasukan faham itu" (Hamka, 1982: 75). Secara historis tahun 1923 merupakan proses awal tumbuhnya organisasi PKI di Indonesia. Ada pun alasan PKI ingin mendirikan partai tersendiri disebabkan terusirnya mereka dari Sarikat Islam (SI). Di Sumatra Barat, khususnya di Padang PKI berdiri pada tahun 1923 yang dipimpin oleh Magas Abdul Madji (Erman, 2005: 183).

Namun, usaha perlawanan ini gagal karena Belanda berhasil mencium gerakan yang dilakukan PKI saat itu. Untuk membalasnya Belanda mulai menumpas semua yang dianggap penentang, akibatnya banyak tokoh-tokoh komunis atau ulama-ulama ekstrimis yang ditangkap. Gagalnya pemberontakan di Padang Panjang, maka pusat kegiatan dipindahkan ke Silungkang. Kepindahan ini juga disebabkan terjadinya gempa bumi dahsyat yang melanda Padang Panjang. Bencana alam ini ditulis Hamka dalam Tenggelamnya Kapal van der Wijck terjadi pada 28 Juni 1926 (Hamka, 1982: 75 dan Kahin, 2005: 21). Bagi tokoh-tokoh komunis jatuhnya pilihan ke Silungkang disebabkan mereka ingin mendekati orang rantai (pekerja tambang) untuk ikut bergabung melawan Belanda. Dalam pandangan mereka, orang rantai merupakan kaum proletar yang bersemangat untuk mengusir penjajah Belanda dari bumi Indonesia.

Dalam konteks roman Tenggelamnya Kapal van der Wijck, Zainuddin adalah simbol orang terusir. Dalam roman dikatakan bahwa Zainuddin merupakan keturunan bangsawan turunan Datuk ri Pandang dan Datuk ri Tirro yang mulamula menanamkan dasar ke-Islaman di Jumpandang (sekarang Ujung Pandang). Menurut adat Makasar perkawinan ibu Zainuddin dengan ayahnya tidak disetujui oleh segenap keluarga lain, sehingga naneknya Daeng Manippi dibenci oleh orang, dan perkawinan ini memutuskan pertalian keluarga (Hamka, 1982: 18). Artinya, keputusan yang diambil Zainuddin untuk pergi ke kampung ayahnya 
(Minangkabau) bukanlah atas kemauannya sendiri, tetapi adat istiadat Makasarlah yang menjadikan Zainuddin menjadi tokoh yang terusir.

Menjadi orang terusir juga dialami oleh Haji Rasul. Beliau terusir dari Thawalib Padang Panjang disebabkan bertambah kuatnya paham PKI yang dikembangkan oleh Natar Zainuddin dan Haji Datuk Batuah di Thawalib Padang Panjang. Sedemikian kuatnya pengaruh paham yang dibawa Natar Zainuddin, banyak kalangan siswa dan kaum muda di Sumatera Thawalib Padang Panjang ikut bergabung mendukung paham tersebut. Akibatnya adalah Belanda dengan leluasa menangkap para guru-guru di Sumatera Thawalib Padang Panjang. Atas peristiwa penangkapan ini semua tudingan mengarah pada haji Rasul. Atas dasar itu pulalah Haji Rasul memutuskan untuk mengundurkan diri dari perguruan Sumatera Thawalib karena beliau dipersalahkan atas tertangkapnya guru-guru muda di perguruan tersebut.

Memang dalam roman Tenggelamnya Kapal van der Wijck yang terusir adalah Zainuddin. Hal itu dalam penciptaan karya sastra proses tersebut lumrah terjadi karena pengarang ingin menutupi realita yang sebenarnya. Selain itu, sebuah karya sastra bukanlah catatan harian yang memuat dokumentasi lengkap dan sesuai dengan realita. Untuk menguatkan peristiwa terusirnya Zainuddin, Hamka menyampaikan lewat sebuah karangan yang ditulis oleh Zainuddin dengan judul "terusir". Karangan itu pun mengingatkan Hayati pada suatu peristiwa yang dialami seorang anak muda di kampungnya dulu (Batipuh). Anak muda itu adalah Zainuddin, ia diusir mamaknya Datuk Batuah.

Keterkaitan lain antara Zainuddin dengan Natar Zainuddin dapat dilihat dari kemunculan tokoh Muluk dalam Tenggelamnya Kapal van der Wijck. Dalam roman dikisahkan bahwa Muluk adalah teman yang paling baik bagi Zainduddin. Ia memiliki arti penting dalam kehidupan Zainuddin. Berkat nasihat Muluk, Zainuddin bangkit dari penderitaannya. Bahkan, Muluk dengan sepenuh hati mengabdikan hidupnya untuk Zainuddin. Melihat keakraban Muluk dan Zainuddin, dapat diasumsikan bahwa hubungan itu merupakan simbol hubungan antara Natar Zainuddin dengan Muluk Nasution.

Muluk adalah seorang lulusan dari Gouvernement Inlandsche School (sekolah rendah pribumi) yang gagal masuk ke Normaal School (sekolah pendidikan guru) di Padang Panjang (Hadler, 2010: 171). Ia mendapat pekerjaan pendukung di suatu pertunjukkan keliling (tonil) di Silungkang. Lebih lanjut dijelaskan Hadler, bahwa sebuah Sekretaris Sarikat Rakyat Silungkang yang kekiri-kirian mempunyai perpustakaan dan di sana Muluk Nasution bisa membaca Jules Verne dan Harriet Beecher Stowe serta tarktat-traktat politik. Sebagai pemain tonil Muluk tentu juga menyebarkan paham komunisnya melalui media tersebut. Pada saat itu, Natar Zainuddin masih belum dibuang ke Digul. Muluk dan Natar Zainuddin berada pada satu paham yang sama dan juga sebagai calon-calon revolusioner yang cukup berpengaruh menyebarkan propaganda komunis di Padang Panjang. Dikurun itu pula Haji Rasul keluar dari Sumatera Thawalib.

Seteleh haji Rasul mengundurkan diri dari Sumatera Thawalib, beliau pulang ke kampung halamanya di Maninjau. Namun, setelah tertangkapnya Natar Zainuddin dan Haji Datuk Batuah, semua sahabat Haji Rasul meminta agar beliau kembali lagi mengajar di Sumatera Thawalib. Tawaran itu diterima Haji rasul. 
Bagi Hamka momen itu juga dikisahkan dalam roman Tenggelamnya Kapal van der Wijck, yakni pada sebuah pertunjukan tonil dengan judul "Kembali" yang ditulis oleh Zainuddin. Dalam konteks tersebut Hamka juga menceritakan keadaan ayahnya yang kembali lagi mengajar di Sumatera Thawalib Padang Panjang.

Sebagai sebuah karya sastra yang mengandung unsur historis, roman Tenggelamnya Kapal van der Wijck telah memberikan sebuah gambaran dialektika kehidupan sejarah sosial di Minangkabau yang melibatkan tiga kekuatan, yakni ulama, politik, dan penjajah. Kedepannya, ketiga kekuatan terus berlanjut sampai diproklamirkannya kemerdekaan Indonesia. Dengan demikian, dapat dikatakan bahwa roman Tenggelamnya Kapal van der Wijck bukanlah plagiat dari karya Mustafa Luthfi Al-Manfaluthi yang berjudul Majdulin atau Magdalena (di Bawah Naungan Pohon Tillia) yang dituduhkan kepada Hamka. Dalam konteks politik tudingan yang dilemparkan kepada Hamka tidak ubah seperti kejadian terusirnya Haji Rasul semasa mengajar di Sumatera Thawali Padang Panjang.

Sejalan dengan apa yang dikemukakan oleh Anwar (1983: 251) perdebatan tetang roman Tenggelamnya Kapal van der Wijck tidak terlepas dari konteks politik saat itu. Lekra atau Lembaga Kebudayaan Rakyat merupakan organisasi pendukung PKI yang melancarkan gerakan menteror orang-orang yang tidak sepaham dengannya. Dalam lapangan sastra satu demi satu pengarang yang dinilai musuh PKI dihantam dan dimusnahkan. Hamka merupakan salah seorang menjadi sasaran Lekra. Hamka dikenal sebagai sastrawan dan ulama muslim terkemuka, dianggap ancaman bagi kelompok berhaluan komunis tersebut. Ia dihantam secara politis karena ia pernah menjadi anggota masyumi. Ia pun dihantam secara mental dengan tuduhan bahwa roman Tenggelamnya Kapal van der Wijck adalah roman plagiat.

\section{PENUTUP}

Berdasarkan analisis yang dilakukan bahwa roman Tenggelamnya Kapal van der Wijck sebagai karya sastra memiliki korelasi atau hubungan dengan realita. Hubungan tersebut dapat dijelaskan dengan konsep repetoire melalui background dan foreground yang dimunculkan teks Tenggelamnya Kapal van der Wijck. Efek atau wirkung tersebut ditangkap oleh pembaca (peneliti) melalui pembaca terhadap karya tersebut.

Repertoire historis dalam roman Tenggelamnya Kapal van der Wijck mewujud dalam background (latar belakang) dan foreground (latar depan). Background di sini mengacu pada teks "paham merah" atau PKI dan foreground pada teks nama tokoh, yaitu Zainuddin dan Muluk serta teks yang terkait dengan Zainuddin, seperti judul drama "Terusir" dan "Kembali" yang ditulisnya. Dengan adanya background dan foreground memberikan efek kepada penulis selaku pembaca (peneliti). Efek itu melahirkan interpretasi bahwa Zainuddin sebagai tokoh roman Tenggelamnya Kapal van der Wijck dapat dianalogikan dengan tokoh realita, yaitu Natar Zainuddin. Demikian juga dengan tokoh Muluk, dapat dikaitkan dengan tokoh sejarah PKI di Padang Panjang dan Silungkang, yaitu Muluk Nasution. Kedua tokoh (Natar Zainuddin dan Muluk Nasution) itu memiliki paham yang sama dan memiliki kedekatan secara emosional. Atas sepak 
Tuab Talino

Tabun XIV Volume 14 Nomor 1 Edisi 31 Juli 2020

ISSN 0216-079X E-ISSN 2685-3043

Balai Bahasa Kalimantan Barat

terjang dan pengaruh kedua tokoh itu eksistensi Haji Rasul mengalami pasang surut di Sumatera Thawalib. Hal itu disiratkan Hamka lewat judul drama "Terusir" dan "Kembali" yang ditulis Zainuddin.

Dengan demikian, penulis berkesimpulan bahwa Tenggelamnya Kapal van der Wijck sebagai sebuah karya sastra mengandung unsur historis, roman tersebut memberikan sebuah gambaran dialektika kehidupan sejarah sosial di Minangkabau yang melibatkan tiga kekuatan, yakni ulama, politik, dan penjajah. Kedepannya, ketiga kekuatan terus berlanjut sampai diproklamirkannya kemerdekaan Indonesia.

\section{DAFTAR PUSTAKA}

Abdullah, S. P. (1962). "Hamka, Benarkah Dia Manfaluthi Indonesia" dalam J. A. Hamzah \& H. B. Jassin, Tenggelamnya Kapal van der Wijck dalam Polemik (1963). Djakarta: Mega Book Store.

Anwar, R. (1983). "Hamka, Gema Insani dan Kumandang Dakwah" dalam Kenang-Kenangan: 70 Tahun Buya Hamka (cetakan ke-3). Jakarta: Pustaka Panjimas.

Dahlan, M. M. (2011). Aku Mendakwa Hamka Plagiat: Skandal Sastra Indonesia 1962-1964. Yogyakarta: SeriPta Manent.

Erman, E. (2005). Membaranya Batubara: Konflik Kelas dan Etnik OmbilinSawahlunto, Sumatera Barat. Jakarta: Desantara.

Hadler, J. (2010). Sengketa Tiada Putus: Matriarkat, Reformisme Islam, dan Kolonialisme di Minangkabau. Jakarta: Freedom Institute.

Hamka. (1982). Tenggelamnya Kapan van der Wijck. Jakarta: Bulan Bintang.

Hamzah, J. A., \& Jassin, H. B. (1963). Tenggelamnya Kapal Van der Wijck dalam Polemik. Djakarta: Mega Book Store.

Junus, U. (1989). Fiksyen dan Sejarah: suatu Dialog. Malaysia: Dewan Bahasa dan Pustaka, Kementerian Pendidikan Malaysia.

Kahin, A. (2005). Dari Pemberontakan ke Integrasi: Sumatera Barat dan Politik Indonesia 1962-1998. Jakarta: Yayasan Obor Indonesia.

Kholidah, U. E., \& Amri, S. H. (2019). "Etnosentrisme Dalam Tenggelamnya Kapal Van Der Wijck Karya Hamka Dalam Perspektif Strukturasi Giddens". Poetika: Jurnal Ilmu Sastra, VII(1), 90-104.

Manshur, F. M. (2007). "Kasidah Burdah Al-Bushiry dan Popularitasnya dalam berbagai Tradisi: Suntingan Teks, Terjemahan, dan Telaah Resepsi". Disertasi. Yogyakata: Universitas Gadjah Mada.

Musyafir, Lembah, G., \& Kangiden, N. (2017). "Ekranisasi Novel Tenggelamnya 
Tuab Talino

Tabun XIV Volume 14 Nomor 1 Edisi 31 Juli 2020

ISSN 0216-079X E-ISSN 2685-3043

Balai Bahasa Kalimantan Barat

Kapal Van Der Wijck Ke Dalam Film (Pendekatan Struktural)". Bahasantodea, 5(2), 76-84.

Nasri, D. (2015). "Ideologeme Novel Tenggelamnya Kapal van der Wijck Karya Hamka: Kajian Intertekstual Julia Kristeva". Thesis. Yogyakarta: Universitas Gadjah Mada.

Rizki D, D. (2017). "Proses Adaptasi ( Ekranisasi ) Novel "Tenggelamnya Kapal Van Der Wijck" Karya Hamka". Jurnal Layar, 4(1), 97-116.

Setyami, I. (2012). "Repertoire dalam Ronggeng Dukuh Paruk Karya Ahmad Tohari: Kajian Estetik Wolfgang Iser". Thesis. Yogyakarta: Universitas Gadjah Mada.

Simarmata, M. Y. (2015). "Analisis Konflik Tokoh Utama Dalam Roman Tenggelamnya Kapal Van Der Wijck Karya Buya Hamka". Jurnal Pendidikan Bahasa, 4(1), 111-124.

Teeuw, A. (1980). Sastra Baru Indonesia (Jilid 1). Ende-Flores: Nusa Indah. 